\title{
PENGARUH GOOD CORPORATE GOVERNANCE TERHADAP MANAJEMEN LABA
}

\author{
Yufenti Oktafia \\ Sekolah Tinggi Ilmu Ekonomi Indocakti Malang \\ Jl Veteran 65145 Malang/No Telphon. 081334731128
}

\begin{abstract}
Earning managements is a management action in the process of preparing financial statements to influence the level of earnings that is displayed. Earnings management is one factor that can reduce the credibility of financial statements. Add to bias earnings management in the financial statements and can interfere with the use of a trusted financial reports profit figures as a result of these engineering profit numbers without engineering. Corporate governance is a concept proposed to improve business performance through supervision or monitoring management performance and ensuring accountability of management to the stakeholders with a framework based on rules. The concept of corporate governance as proposed for the achievement of corporate management more transparent to all users of financial statements. If this concept is applied properly it is expected that economic growth will continue to rise in line with the transparency of corporate management a better and will benefit many parties. Detection possibility of earnings management in the financial statements, examined through the use of estimates of total accruals. Total accruals consist of nondiscretionary accrual and discretionary accruals. Earnings management occurs because of opposition from various interested parties on the financial statement information, which interested parties on financial statements information that is internal and external parties. Conflicts of interest that occurs is minimized by a mechanism that is capable of aligning the interests of external and internal parties. Agency theory suggests that earnings management issues can be eliminated with the supervision of their own through good corporate governance.
\end{abstract}

Keywords: corporate governance, discretionary accrual

\section{PENDAHULUAN}

Perusahaan publik merupakan perusahaan yang sebagian sahamnya telah dimiliki oleh masyarakat melalui bursa saham. Perusahaan ini memiliki kewajiban untuk menyajikan laporan keuangan sesuai dengan persyaratan yang ditetapkan oleh lembaga yang berwenang di Indonesia, lembaga ini adalah BAPEPAM 
(Badan Pengawas Pasar Modal). Penyampaian informasi melalui laporan keuangan ini perlu dilakukan untuk memenuhi kebutuhan pihak-pihak eksternal maupun internal yang memiliki wewenang untuk memperoleh informasi yang mereka butuhkan dari sumber langsung perusahaan. Salah satu informasi yang terdapat dalam laporan keuangan adalah informasi mengenai laba perusahaan.

Media komunikasi yang biasa digunakan untuk menghubungkan kepentingan pihak-pihak ini adalah laporan keuangan. Menurut Belkoui dalam Rahmania (2007), laporan keuangan merupakan salah satu sumber utama informasi keuangan yang penting bagi sejumlah pemakai dalam pengambilan keputusan ekonomi. Laporan keuangan juga merupakan sarana untuk mempertanggungjawabkan apa yang dilakukan oleh manajemen atas sumber daya pemilik. Laporan keuangan yang lengkap biasanya meliputi neraca, laporan laba rugi, laporan perubahan modal, laporan arus kas dan catatan atas laporan keuangan (SAK No 1 Paragraph 7).

Laporan laba sebagai produk informasi yang dihasilkan perusahaan, tidak terlepas dari proses penyusunannya. Adanya kecenderungan untuk memperhatikan laba ini didasari oleh sikap manajemen yang cenderung mendorong timbulnya earning management. Sehingga akhir-akhir ini laporan keuangan telah menjadi isu sentral sebagai sumber manipulasi dari informasi yang dapat merugikan bagi pihak-pihak yang berkepentingan.

Manajemen laba dapat terjadi pula karena manajer diberi keleluasaan untuk memilih metode akuntansi yang akan digunakan dalam mencatat dan mengungkapkan informasi keuangan privat yang dimilikinya. Laporan keuangan yang disajikan oleh pihak manajemen dapat direkayasa untuk menghasilkan tingkat laba yang diinginkan dalam mencapai tujuan tertentu yang dapat menyesatkan pemilik, pemegang saham atau calon investor yang menggunakan laporan keuangan tersebut. Earning management dilakukan agar seolah-olah laba memiliki kualitas laba yang baik dan stabil, dengan harapan laba yang dilaporkan mendapat respon positif oleh pasar (Kusindratno dan Sumarta, 2005).

Deteksi atas kemungkinan dilakukanya manajemen laba dalam laporan keuangan, diteliti melalui penggunaan estimasi total akrual. Total akrual terdiri dari nondiscretionary accrual (normal akrual) dan discretionary accrual 
(abnormal akrual). Menurut Satwika dan Damayanti (2005), normal akrual merupakan pengakuan akrual yang wajar dan tunduk pada suatu standar atau peraturan akuntansi yang berlaku umum. Sebaliknya, abnormal akrual merupakan pengakuan akrual yang bebas, tidak diatur dan merupakan pilihan kebijakan manajemen. Akrual yang digunakan untuk melakukan manajemen laba adalah discretionary accrual (abnormal akrual).

Dalam teori keagenan (agency theory), hubungan agensi muncul ketika satu orang atau lebih (principal) mempekerjakan orang lain (agent) untuk memberikan suatu jasa dan kemudian mendelegasikan wewenang pengambilan keputusan kepada agent tersebut (Jensen dan Meckling, 1976). Manajer sebagai pengelola perusahaan lebih banyak mengetahui informasi internal dan prospek perusahaan di masa yang akan datang dibandingkan pemilik (pemegang saham). Oleh karena itu sebagai pengelola, manajer berkewajiban memberikan sinyal mengenai kondisi perusahaan kepada pemilik. Akan tetapi informasi yang disampaikan terkadang diterima tidak sesuai dengan kondisi perusahaan sebenarnya (Ujiyanto dan Pramuka, 2007). Kondisi ini dikenal sebagai informasi yang tidak simetris atau asimetri informasi (information asymmetric).

Kusindratno dan Sumarta (2005) menyatakan bahwa manajemen laba terjadi karena adanya pertentangan dari berbagai pihak yang berkepentingan terhadap informasi laporan keuangan, yaitu pihak yang berkepentingan terhadap informasi laporan keuangan yaitu pihak internal dan eksternal. Pertentangan yang dapat terjadi antara pihak-pihak tersebut antara lain:

1. Manajemen berkeinginan meningkatkan kesejahteraannya sedangkan pemegang saham berkeinginan meningkatkan kekayaannya.

2. Manajemen berkeinginan memperoleh kredit sebesar mungkin dengan bunga rendah sedangkan kreditor hanya ingin memberi kredit sesuai dengan kemampuan perusahaan.

3. Manajemen berkeinginan membayar pajak sekecil mungkin sedangkan pemerintah ingin memungut pajak seminimal mungkin.

Konflik kepentingan yang terjadi diminimalkan dengan suatu mekanisme yang mampu mensejajarkan kepentingan pihak eksternal dan pihak internal. Agency theory memberikan gambaran bahwa masalah manajemen laba dapat 
dieliminasi dengan pengawasan sendiri melalui good corporate governance. Corporate governance merupakan mekanisme pengendalian untuk mengatur dan mengelolah bisnis dengan maksud untuk meningkatkan kemakmuran dan akuntabilitas perusahaan yang tujuan akhirnya untuk mewujudkan shareholder value. lsu corporate governance muncul karena terjadi pemisahan antara kepemilikan dan pengelolaan perusahaan (Barle dan Means dalam Gunarsih, 2003).

Corporate governanace diperlukan untuk mengendalikan perilaku pengelola perusahaan agar bertindak tidak hanya menguntungkan dirinya sendiri, tetapi juga menguntungkan pemilik perusahaan, atau dengan kata lain untuk menyamakan kepentingan antara pemilik perusahaan dengan mengelola perusahaan. Sedangkan, menurut Veronica dan Bactiar (2006) beberapa mekanisme corporate governance antara lain diwujudkan dewan direksi, komite audit, kualitas audit, dan kepemilikan institusional.

\section{PEMBAHASAN}

\section{Teori Keagenan}

Pemegang saham sebagai pihak prinsipal mengadakan kontrak untuk memaksimalkan kesejahteraan dirinya dengan profitabilitas yang selalu meningkat. Masalah keagenan muncul karena adanya oportunistik dari agen yaitu perilaku manajemen untuk memaksimumkan kesejahteraan sendiri yang berlawanan dengan kepentingan prinsipal. Manajer memiliki dorongan untuk memilih dan menerapkan metoda akuntansi yang dapat memperlihatkan reaksi pasarnya yang baik untuk tujuan mendapatkan bonus prinsipal.

Jensen dan Meckling (1976) menyatakan bahwa hubungan teori keagenan adalah sebuah kontrak antara manajer (agent) dengan investor (principal). Konflik kepentingan antara pemilik dan agen terjadi kemungkinan agen tidak selalu berbuat sesuai dengan kepentingan principal, sehingga memicu biaya keagenan (agency cost). Pemisahan kepemilikan dan pengendalian menyebabkan manajemen (agent) bertindak sesuai dengan kepentingan principal (pemilik).

Jensen dan Meckling (1976) mengidentifikasi biaya keagenan menjadi tiga kelompok, yaitu: (a) the monitoring expenditure by principal adalah biaya 
pengawasan yang harus dikeluarkan olek pemilik, (b) the bonding cost adalah biaya yang harus dikeluarkan akibat pemonitoran yang harus dikeluarkan principal (pemilik) kepada agen, (c) the residual cost adalah pengorbanan akibat berkurangnya kemakmuran principal (pemilik) karena perbedaan keputusan antara principal (pemilik) dan agent.

Pemilik perusahaan publik mengalami kesulitan dalam mengendalikan perusahaan secara langsung karena: (a) ukuran perusahaan yang semakin besar sehingga sulit untuk mengelolanya sendiri, (b) memerlukan keahlian khusus yang kompleks dalam mengelola organisasi yang besar dimana umumnya pemilik memiliki keterbatasan dalam hal ini, (c) kepemilikan perusahaan ditentukan oleh jumlah saham yang dimiliki yang berarti pemilik bisa lebih dari satu orang atau organisasi sehingga tidak memungkinkan apabila seluruh pemilik menjalankan operasi perusahaan.

\section{Manajemen Laba}

Setiawati dan Na'im (2000) mendefinisikan manajemen laba adalah campur tangan manajemen dalam proses pelaporan keuangan eksternal dengan tujuan untuk menguntungkan dirinya sendiri. Manajemen laba merupakan satu faktor yang dapat mengurangi kredibilitas laporan keuangan. Manajemen laba menambah bias dalam laporan keuangan dan dapat menggangu pemakaian laporan keuangan yang mempercayai angka laba hasil rekayasa tersebut sebagai angka laba tanpa rekayasa.

Menurut Wedari (2004) Manajemen laba adalah manipulasi laba yang dilakukan pihak manajemen untuk mencapai tujuan tertentu. Manipulasi dilakukan agar laba nampak sebagaimana yang diharapkan. Manipulasi juga dilakukan agar investor tetap tertarik dengan perusahaan tersebut. Menurut Scott (2003:354) mendefinisikan earning management sebagai berikut:

"Given that managers can choose accounting policies so as to maximize their own utility and/on market value of the firm."

Dechow dan Skinner dalam Kusuma (2006), menyebutkan dua definisi yang sudah dapat diterima secara luas, yaitu: 
1. Manajemen laba adalah suatu intervensi yang disengaja dilakukan dengan maksud tertentu terhadap proses pelaporan keuangan eksternal untuk memeperoleh beberapa keuntungan pribadi.

2. Manajemen laba terjadi ketika para manajer menggunkan judgement dalam pelaporan keuangan dan penyusunan transaksi untuk merubah laporan keuangan yang menyesatkan terhadap pemegang saham atas dasar kinerja ekonomi organisasi atau untuk mempengaruhi hasil sesuai dengan komtrak yang tergantung pada angka-angka akuntansi yang dilaporkan.

Sugiri dalam Widyaningdyah (2001) membagi definisi earning management menjadi dua, yaitu:

1. Definisi sempit

Earning management dalam hal ini hanya berkaitan dengan pemilihan metode akuntansi. Earning management dalam artian sempit ini didefinisikan sebagai perilaku manajer untuk "bermain" dengan komponen discretionary accruals dalam menentukan besarnya earning.

2. Definisi Luas

Earning management merupakan tindakan manajer untuk meningkatkan (mengurangi) laba yang dilaporkan saat ini atas suatu unit dimana manajer bertanggungjawab, tanpa mengakibatkan peningkatan (penurunan) profitabilitas ekonomi jangka panjang unit tersebut.

Menurut Surifah dalam Widyaningdyah (2001) earning management dapat mengurangi kredibilitas laporan keuangan apabila digunakan untuk pengambilan keputusan, karena earning management merupakan suatu bentuk manipulasi atas laporan keuangan yang menjadi sarana komunikasi manajer dan pihak eksternal perusahaan. Mengacu pada pendapat di atas maka earning management dinyatakan dalam perspektif opurtunitis. Sedangkan menurut Beneish (2001) membagi earning management menjadi:

1. Mengelola penghasilan adalah "proses mengambil langkah-langkah yang disengaja dalam batasan prinsip akuntansi yang berlaku umum untuk menghasilkan tingkat laba yang dilaporkan diinginkan.

2. Mengelola laba adalah tujuan intervensi dalam proses pelaporan keuangan eksternal, dengan maksud untuk memperoleh beberapa keuntungan pribadi. 
3. Manajemen laba terjadi ketika manajer menggunakan penilaian dalam pelaporan keuangan dan struktur transaksi untuk mengubah laporan keuangan yang baik untuk menyesatkan beberapa stakeholder tentang kinerja ekonomi yang yang mendasai perusahaan atau untuk mempengaruhi hasil kontrak yang tergantung pada angka akuntansi yang dilaporkan.

Menurut Healy dan Wahlen (1998)

"Earning management occurs when managers use judgment in financial reporting and in structuring transactions to alter financial reports to either mislead some stakeholders about the underlying economic performance of the company, or to influence contractual outcomes that depend on reported accounting numbers.”

Assih dan Gudono (2000) mendefinisikan manajemen laba sebagai suatu proses yang dilakukan dengan sengaja dalam batasan general accepted accounting principles untuk mengarah pada suatu tingkat yang diinginkan atas laba yang dilaporkan. Sedangkan menurut Djakman (2003) manajemen laba dapat dilakukan melalui kebijakan akrual. Untuk memahami apa yang dimaksud dengan kebijakan akrual, berikut ini kutipan definisi kebijakan akrual dari Financial Accounting Standard Board (FASB, 1978):

"Accrual accounting attempts to record the financial effects on an entity of transactions and other events and circumstances the have cash consequences for the entity in the periods in which those transactions, events, and circumstances occur rather than only in the periods in which cash is received or paid by the entity ".

\section{Faktor-Faktor Pemicu Manajemen Laba}

Setiawati dan Na'im (2000) faktor-faktor pemicu manajemen laba dalam kaitannya dengan pihak-pihak yang berkepentingan tersebut adalah pemakai informasi akuntansi antara lain:

a. Dalam kontrak antara manajer dan pemilik (melalui kompensasi)

b. Sebagai sumber investor bagi investor di pasar modal

c. Dalam kontrak hutang 
d. Dalam penetapan pajak oleh pemerintah, penentuan proteksi terhadap produk, penentuan denda dalam suatu kasus

e. Oleh pesaing seperti untuk penentuan keputusan ambil alih ataupun untuk penetapan strategi persaingan

f. Oleh karyawan untuk meminta kenaiakn upah

Beneish dalam Kusuma (2006) menyatakan ada dua motivasi utama para menajer melakukan manajemen laba, yaitu opportunities dan informasi (signaling) kepada investor. Tujuan opportunities mungkin dapat merugikan pemakai laporan keuangan karena informasi yang disampaikan manajemen menjadi tidak akurat dan juga tidak menggambarkan nilai fundamental perusahaan. Tujuan informatif (signaling) kemingkinan besar membawa dampak yang baik bagi pemakai laporan keuangan. Manajer berusaha menginformasikan kesempatan yang dapat diraih oleh perusahaan dimasa yang akan datang. Oleh karena itu, manajer dapat mengestimasi secara baik laba masa datang dan diinformasikan kepada investor atau para pemakai lapoaran keuangan lainya.

Menurut Halim et al., (2005) perilaku manajemen laba dapat dijelaskan melalui Positive Accounting Theory (PAT) dan Agency Theory. Tiga hipotesis PAT yang dijadikan dasar pemahaman tindakan manajemen laba yang dirumuskan oleh Watts dan Zimmerman dalam Scott (2003:287) adalah sebagai berikut:

a) The Bonus Plan Hypothesis

Pada perusahaan yang memiliki rencana pemberian bonus, manajer perusahaan akan lebih memilih metode akuntansi yang dapat menaikkan laba saat ini. Hal ini dikarenakan manajer lebih menyukai pemberian upah yang lebih tinggi untuk masa kini.

b) The Debt Convenant Hypothesis

Pada perusahaan yang mempunyai rasio debt to equity tinggi, manajer perusahaan cenderung menggunakan metode akuntansi yang dapat meningkatkan pendapatan atau laba. Hal ini disebabkan karena perusahaan dengan rasio debt to equity yang tinggi akan mengalami kesulitan dalam memperoleh dana tambahan dari pihak kreditor bahkan perusahaan terancam melanggar perjanjian hutang. 
c) The Political Cost Hypothesis

Pada perusahaan besar yang memiliki biaya politik tinggi, manajer perusahaan akan lebih memilih metode akuntansi yang menangguhkan laba yang dilaporkan dari periode sekarang ke periode masa mendatang sehingga dapat memperkecil laba yang dilaporkan. Biaya politik muncul dikarenakan profitabilitas perusahaan yang tinggi dapat menarik perhatian media dan konsumen.

Menurut Scott dalam Wedari (2004), motivasi perusahaan dalam hal ini manajer melakukan manajemen laba adalah :

1. Bonus scheme (rencana bonus) merupakan motivasi manajer yang bekerja di perusahaan dengan rencana bonus akan berusaha mengatur laba yang dilaporkan agar dapat memaksimalkan bonus yang akan diterimanya.

2. Debt covenant (kontrak hutang jangka panjang) yaitu motivasi yang sejalan dengan hipotesis debt covenant dalam teori akuntansi positif yaitu semakin dekat suatu perusahaan ke pelanggaran perjanjian hutang maka manajer akan cenderung memilih metode akuntansi yang dapat "memindahkan" laba periode mendatang ke periode berjalan sehingga dapat mengurangi kemungkinan perusahaan mengalami pelanggaran kontrak.

3. Political motivation (motivasi politik) yaitu motivasi dari perusahaanperusahaan besar dan industri strategis yang cenderung menurunkan laba untuk mengurangi visibilitasnya, khususnya selama periode kemakmuran tinggi. Tindakan ini dilakukan untuk memperoleh kemudahan dan fasilitas dari pemerintah misalnya subsidi.

4. Taxation motivation (motivasi perpajakan), perpajakan merupakan salah satu alasan utama mengapa perusahaan mengurangi laba yang dilaporkan. Dengan mengurangi laba yang dilaporkan maka perusahaan dapat meminimalkan besar pajak yang harus dibayarkan kepada pemerintah.

5. Pergantian $C E O, C E O$ yang akan habis masa penugasannya atau pensiun akan melakukan strategi memaksimalkan laba untuk meningkatkan bonusnya. Demikian pula dengan $C E O$ yang kinerjanya kurang baik, ia akan cenderung memaksimalkan laba untuk mencegah atau membatalkan pemecatannya. 
6. Initial Public Offering (penawaran saham perdana), pada saat perusahaan go public, informasi keuangan yang ada dalam prospektus merupakan sumber informasi yang penting. Informasi ini dapat dipakai sebagai sinyal kepada calon investor tentang nilai perusahaan. Untuk mempengaruhi keputusan calon investor maka manajer berusaha menaikkan laba yang dilaporkan.

\section{Bentuk-bentuk dan Teknik manajemen laba}

Scott dalam Kusindratno dan Sumarta (2005) mengemukakan bentukbentuk manajemen laba yang dilakukan oleh manajer antara lain :

1. Taking a bath, dilakukan ketika keadaan buruk yang tidak menguntungkan tidak bisa dihindari pada periode berjalan, dengan cara mengakui biaya-biaya pada periode-periode yang akan datang dan kerugian periode berjalan.

2. Income minimization, dilakukan saat perusahaan memperoleh profitabilitas yang tinggi dengan tujuan agar tidak mendapat perhatian secara politis. Kebijakan yang diambil bisa berupa pembebanan pengeluaran iklan, riset dan pengembangan yang cepat dan sebagainya. Cara ini mirip dengan taking a bath namun kurang ekstrim.

3. Income maximization, yaitu memaksimalkan laba agar memperoleh bonus yang lebih besar. Demikian pula dengan perusahaan yang mendekati suatu pelanggaran kontrak hutang jangka panjang, manajer perusahaan tersebut akan cenderung untuk memaksimalkan laba.

4. Income smoothing, merupakan bentuk manajemen laba yang paling sering dilakukan dan paling populer. Lewat income smoothing, manajer menaikkan atau menurunkan laba untuk mengurangi fluktuasi laba yang dilaporkan sehingga perusahaan terlihat stabil dan tidak beresiko tinggi.

Menurut Worthy dalam Irfan (2002) fleksibilitas dalam menghitung jumlah angka laba berasal dari: (1). Metode akuntansi yang memberikan peluang bagi manajemen untuk untuk mencatat suatu fakta tertentu dengan cara yang berbeda, (2). Metode akuntansi memberikan peluang bagi manajemen untuk melihat subjektivitas dalam melakuan estimasi. Sedangkan teknik-teknik manajemen laba dapat dikelompokkan menjadi tiga kelompok yaitu:

1. Memanfaatkan peluang untuk membuat ekstimasi akuntansi. Cara manajemen untuk mempengaruhi laba melalui judgement terhadap estimasi akuntansi 
antara lain: estimasi tingkat piutang tak tertagih, estimasi kurun waktu depresiasi aktiva tetap atau amortisasi aktiva tak berwujud.

2. Perubahan metode akuntansi, yaitu dengan mengubah metode akuntansi yang berbeda dengan metode sebelumnya sehingga dapat menaikkan atau menurunkan angka laba. Misalnya dengan mengubah metode depresiasi, mengubah metode penilaian persediaan.

3. Menggeser periode biaya atau pendapatan, sering disebut dengan manipulasi operasional, misalnya mempercepat atau menunda pengeluaran untuk penelitian atau pengembangan promosi sampai periode akuntansi berikutnya.

\section{Corporate Governance}

Corporate governance merupakan konsep yang diajukan demi peningkatan kinerja perusahaan melalui supervisi atau monitoring kinerja manajemen dan menjamin akuntabilitas manajemen terhadap stakeholder dengan mendasarkan pada kerangka peraturan. Konsep corporate governance diajukan demi tercapainya pengelolaan perusahaan yang lebih transparan bagi semua pengguna laporan keuangan.

Menurut bank dunia dalam Nuryanah (2004), corporate governance adalah standar aturan dan standar organisasi di bidang ekonomi yang mengatur perilaku pemilik perusahaan, direktur dan manajer serta pertanggungjawabannya terhadap investor (pemegang saham dan kreditur).

Pranoto dalam Nuryanah (2004) menyatakan definisi corporate governance menurut OECD (Organisation for Economic Co-operation and Development) yaitu cara-cara manajemen perusahaan (yaitu para direktur) bertanggung jawab kepada pemiliknya (yakni pemegang saham). Para pengambil keputusan atas nama perusahaan adalah dapat dipertanggungjawabkan, menurut tingkatan yang berbeda pada pihak lain yang dipengaruhi oleh keputusan tersebut, termasuk perusahaan itu sendiri, para pemegang saham, kreditur dan para publik penanam modal.

Menurut Surat Edaran Menteri Negara Pasar Modal dan Pengawas BUMN No. S.106/M.PM P.BUMN/2000 dalam Nuryanah (2004) good corporate governance adalah segala hal yang berkaitan dengan pengambilan keputusan yang 
efektif yang bersumber dari budaya perusahaan, etika, nilai, sistem, proses bisnis, kebijakan dan struktur organisasi perusahaan yang bertujuan untuk mendorong dan mendukung adanya pengembangan perusahaan, pengelolaan sumber daya dan risiko secara lebih efisien dan efektif, serta pertanggungjawaban perusahaan kepada pemegang saham dan stakeholder lainnya.

Darmawati (2003), mendefinisikan Corporate Governance sebagai hubungan di antara berbagai pihak yang berperan serta dalam menentukan arah dan kinerja perusahaan. Pemeran serta utama adalah pemegang saham, pengurus (yang dipimpin oleh direktur utama/CEO), dan Pengawas.

Finance Committee on Corporate Governance Malaysia dalam Herwidayatmo (2000), mendefinisikan Corporate Governance sebagai proses dan struktur yang digunakan untuk mengarahkan dan mengelola bisnis dan kegiatan perusahaan ke arah peningkatan pertumbuhan bisnis dan akuntabilitas perusahaan. Adapun tujuan akhirnya adalah meningkatkan kemakmuran pemegang saham dalam jangka panjang dengan tetap memperhatikan kepentingan stakeholders yang lain.

Menurut Khomsiyah ( 2003) Corporate Governance merupakan suatu cara untuk menjamin bahwa manajemen bertindak yang terbaik untuk kepentingan stakeholders. Pelaksanaan good corporate governance menuntut adanya perlindungan yang kuat terhadap hak-hak pemegang saham, terutama pemegang saham minoritas. Prinsip-prinsip atau pedoman pelaksanaan Corporate Governance menunjukkan adanya perlindungan tersebut, tidak hanya kepada pemegang saham, tetapi meliputi seluruh pihak yang terlibat dalam perusahaan termasuk masyarakat.

Menurut Wardhani (2006) Corporate Governance (CG) merupakan tata kelola perusahaan yang menjelaskan hubungan antara berbagai partisipan dalam perusahaan yang menentukan arah dan kinerja perusahaan. Isu mengenai CG ini mulai mengemuka, khususnya di Indonesia, setelah Indonesia mengalami masa krisis yang berkepanjangan sejak tahun 1998. Banyak pihak yang mengatakan lamanya proses perbaikan di Indonesia disebabkan oleh sangat lemahnya CG yang diterapkan dalam perusahaan di Indonesia. 
Menurut Griffin dalam Susiana dan Herawati (2007) pengertian corporate governance adalah :

"The roles of shareholders, directors and other managers in corporate decision making”.

\section{Tujuan Corporate Governance}

Tujuan utama corporate governance seperti yang dinyatakan dalam OECD adalah:

1. Untuk mengurangi kesenjangan (gap) antara pihak-pihak yang memiliki kepentingan dalam suatu perusahaan (pemegang saham mayoritas dan pemegang saham lannya).

2. Meningkatkan kepercayaan bagi para investor dalam melakukan investasi.

3. Mengurangi biaya modal (cost of capital).

4. Meyakinkan kepada semua pihak atas komitmen legal dalam pengelolaan perusahaan.

5. Menciptakan nilai bagi perusahaan termasuk hubungan antara para stakeholders (kreditur, investor, karyawan perusahaan, bondholders, pemerintah dan shareholders).

\section{Mekanisme corporate governance}

Menurut Walsh dan Seward dalam Gunarsih (2003) terdapat dua jenis mekanisme untuk membantu menyamakan perbedaan kepentingan antara manajer dan pemegang saham (shareholder) yaitu mekanisme pengendalian perusahaan perusahaan internal dan mekanisme pengendalian berdasarkan pasar. Mekanisme pengendalian internal didesain untuk menyamakan kepentingan antara manajer dan pemegang saham.

Menurut Riyanto (2005) secara umum corporate governance menyangkut sarana, mekanisme yang berperan sebagai cek atau self-serving behaviour manajer. Pengelolan perusahaan yang terbuka (transparent) dan accountable bisa mencegah terjadinya bisa mencegah terjadinya self-serving behaviour. Good corporate governance dengan demikian bisa diartikan sebagi interaksi antar struktur dan mekanisme yang menjamin adanya control dan accountability, namun tetap mendorong efisiensi dan kinerja perusahaan. Faktor utama yang 
mendorong terciptanya effective corporate governance adalah internal auditors, board of director, senior management, dan external auditors.

\section{Prinsip-prinsip Corporate governance}

Masalah corporate governance juga menjadi perhatian Indonesia. FCGI (2001) menuliskan prnsip-prinsip Internasional mengenai corporate governance, antara lain mencakup:

1. Perlindungan terhadap hak-hak pemegang saham (the rights of shareholders) Hak-hak para pemegang saham, yang harus diberi informasi dengan benar, dan tepat pada waktunya mengenai perusahaan, dapat ikut berperan serta dalam pengambilan keputusan mengenai perubahan-perubahan yang mendasar atas perusahaan, dan turut memperoleh bagian dari keuntungan perusahaan.

2. Perlakuan yang sama terhadap seluruh pemegang saham (the Equitable Treatment of Stakeholders)

Perlakuan yang sama terhadap pemegang saham, terutama terhadap para pemegang saham minoritas dan para pemegang saham asing, dengan kerterbukaan informasi yang penting serta melarang pembagian untuk pihak sendiri dan perdagangan saham lain.

3. Peranan stakeholder yang terkait dengan perusahaan (the Roles of Stakeholder)

Peranan pemegang saham harus diakui sebagaimana ditetapkan oleh hukum dan kerjasama yang aktif antar perusahaan serta pemegang kepentingan dalam menciptakan kekayaan, lapangan kerja dan perusahaan yang sehat dari aspek keuangan.

4. Keterbukaan dan transparansi (Disclosure and Transparency) Pengungkapan yang akurat dan tepat waktu serta transparansi mengenai semua hal yang penting bagi kinerja perusahaan, kepemilikan, serta para pemegang kepentingan.

5. Akuntabilitas Dewan Komisaris (The Responsibility of The Board) Tanggung jawab pengurus dalam manajemen, pegawasan manajemen serta pertanggungjawaban kepada perusahaan pemegang saham. 
Sebagaimana yang diuraikan oleh OECD (Orgainzational For Economic Co-operation and Development), (2004), terdapat empat prinsip dasar pengelolaan perusahaan yang baik. Ke empat prinsip tersebut adalah :

1. Keadilan (fairness) yang meliputi :

a. Perlindungan bagi seluruh hak pemegang saham.

b. Perlakuan yang sama bagi para pemegang saham.

2. Transparansi (transparancy) yang meliputi:

a. Pengungkapan informasi yang bersifat penting.

b. Informasi harus disiapkan, diaudit dan diungkapkan sejalan dengan pembukuan yang berkualitas.

c. Penyebaran informasi harus bersifat adil, tepat waktu dan efisien.

3. Dapat dipertanggungjawabkan (accountability) yang meliputi pengertian:

a. Anggota dewan direksi harus bertindak mewakili kepentingan perusahaan dan para pemegang saham.

b. Penilaian yang bersifat independent terlepas dari manajemen.

c. Adanya akses terhadap informasi yang akurat, relevan dan tepat waktu

4. Pertanggungjawaban (responsibility) meliputi:

a. Menjamin dihormatinya segala hak pihak-pihak yang berkepentingan.

b. Para pihak yang berkepentingan harus mempunyai kesempatan untuk mendapatkan ganti rugi yang efektif atas pelanggaran hak-hak mereka.

c. Dibukanya mekanisme pengembangan prestasi bagi keikutsertaan pihak yang berkepentingan.

d. Jika diperlukan, para pihak yang berkepentingan harus mempunyai akses terhadap informasi yang relevan.

Dimana prinsip-prinsip yang disusun oleh $O E C D$, (2004) yang bertujuan untuk mewujudkan atau mengembangkan good corporate governance sebagaimana yang dikutip oleh Darmawati (2003), adalah sebagai berikut:

a. Hak-hak pemegang saham

Kerangka kerja corporate governance harus melindungi hak-hak pemegang saham.

b. Perlakuan yang adil kepada pemegang saham 
Kerangka kerja corporate governance harus meyakinkan adanya kesetaraan perlakuan kepada seluruh pemegang saham, termasuk pemegang saham minoritas dan asing.

c. Peranan stakeholders dalam corporate governance

Kerangka kerja corporate governance harus mengakui hak-hak stakeholders seperti yang ditentukan oleh hukum dan mendorong kerjasama yang aktif antara perusahaan dan stakeholders dalam penciptaan kesejahteraan, pekerjaan-pekerjaan, dan kemampuan untuk mempertahankan perusahaan yang sehat secara finansial.

d. Pengungkapan dan transparansi

Kerangka kerja corporate governance harus meyakinkan bahwa pengungkapan yang tepat waktu dan akurat telah dilakukan atas seluruh hal-hal yang material berkenaan dengan perusahaan, termasuk situasi keuangan, kinerja, kepemilikan, dan ketaatan perusahaan (governance of the company).

e. Tanggung jawab dewan

Kerangka kerja corporate governance harus meyakinkan pedoman strategik perusahaan, pemonitoran yang efektif pada manajemen oleh dewan dan akuntabilitas dewan terhadap perusahaan dan pemegang saham.

\section{Konsep Corporate Governance.}

Menurut Dahlan (2003) mengapa corporate governance sangat penting? Ada beberapa alasan Corporate governance begitu penting adalah sebagai berikut:

1. Krisis moneter yang melanda Asia

Selain instabilitas pasar finansial internasional dan krisis nilai tukar, faktorfaktor yang menjadi pendorong krisis moneter adalah adanya kelemahan struktural dalam ekonomi khususnya negara Asia.

2. Meningkatnya tuntutan akuntabilitas

Ditinjau dari perspektif kebijakan publik, corporate governance adalah berkaitan dengan pemeliharaan perusahaan serta menjamin adanya 
akuntabilitas dalam menjalankan kekuasaan dan perlindungan oleh perusahaan.

3. Munculnya pasar modal

Paham globalisasi telah menggema di seluruh dunia. Perkembangan ini turut mempengaruhi kondisi pasar dan investasi yang ada. Munculnya tuntutan globalisasi mendorong para investor besar untuk mencapai peluang investasi yang atraktif di luar pasar domestik.

Konsep corporate governance merupakan konsep universal namun dalam pelaksanaannya harus disesuaikan dengan kondisi masing-masing negara. OECD memberikan suatu sikap bahwa ada enam komponen utama dalam mekanisme corporate governance agar konsep corporate governance dapat berjalan dengan baik yaitu:

a. Dasar keyakinan untuk menerapkan konsep corporate governance yang efektif (penjelasan mengenai transparasi dalam laporan keuangan seperti tanggung jawab perusahaan, fungsi pengawasan oleh manajemen perusahaan).

b. Hak dari para pemegang perusahaan (shareholder) dimana perusahaan harus melindungi kepentingan para pemegam saham.

c. Perlakuan yang sesuai dari terhadap para pemilik perusahaan baik pemilik mayoritas dan minoritas seperti hak untuk meminta informasi berkaitan dengan perusahaan.

d. Peran para pemilik dalam mekanisme corporate governance seperti hak yang dimiliki oleh oleh pemilik terhadap transfer-wealth yang harus dilakukan oleh manajemen perusahaan.

e. Transparasi dan pengungkapan yang memadai dalam laporan keuangan.

f. Tanggung jawab dari para direktur (board of directors).

\section{Manfaat dan Keuntungan Corporate Governance}

Dengan dilaksanakannya corporate governance, menurut Maksum (2005) terdapat beberapa manfaat yaitu: 
a. Meningkatkan kinerja perusahaan melalui terciptanya proses pengambilan keputusan yang lebih baik, meningkatkan efisiensi dan terciptanya budaya kerja yang sehat.

b. Meminimalkan kerugian akibat penyalahgunaan wewenang oleh direksi (agency cost) dan penyimpangan dalam pengelolaan keuangan.

c. Meningkatkan kepercayaan investor dan pada akhirnya meningkatkan pula value saham perusahaan.

d. Dengan adanya peningkatan kinerja perusahaan akan meningkatkan pula shareholder's value dan dividen.

e. Praktek good corporate governance menempatkan karyawan sebagai salah satu stakeholders yang harus dikelola dengan baik sehingga akan meningkatkan motivasi dan kepuasan kerja karyawan dan pada akhirnya dapat meningkatkan produktivitas perusahaan.

f. Meningkatkan citra positif perusahaan sekaligus meminimalkan cost akibat tuntutan stakeholders kepada perusahaan.

g. Meningkatkan kualitas laporan keuangan, karena manajemen akan cenderung untuk tidak melakukan rekayasa terhadap laporan keuangan, karena adanya kewajiban untuk mematuhi berbagai aturan dan prinsip akuntansi yang berlaku dan penyajian informasi secara transparan.

\section{SIMPULAN}

Laporan laba sebagai produk informasi yang dihasilkan perusahaan, tidak terlepas dari proses penyusunannya. Adanya kecenderungan untuk memperhatikan laba ini didasari oleh sikap manajemen yang cenderung mendorong timbulnya earning management. Sehingga akhir-akhir ini laporan keuangan telah menjadi isu sentral sebagai sumber manipulasi dari informasi yang dapat merugikan bagi pihak-pihak yang berkepentingan. Manajemen laba dapat terjadi pula karena manajer diberi keleluasaan untuk memilih metode akuntansi yang akan digunakan dalam mencatat dan mengungkapkan informasi keuangan privat yang dimilikinya.

Laporan keuangan yang disajikan oleh pihak manajemen dapat direkayasa untuk menghasilkan tingkat laba yang diinginkan dalam mencapai tujuan tertentu 
yang dapat menyesatkan pemilik, pemegang saham atau calon investor yang menggunakan laporan keuangan tersebut. Earning management dilakukan agar seolah-olah laba memiliki kualitas laba yang baik dan stabil, dengan harapan laba yang dilaporkan mendapat respon positif oleh pasar (Kusindratno dan Sumarta, 2005). Deteksi atas kemungkinan dilakukanya manajemen laba dalam laporan keuangan, diteliti melalui penggunaan estimasi total akrual. Total akrual terdiri dari nondiscretionary accrual (normal akrual) dan discretionary accrual (abnormal akrual).

Konflik kepentingan yang terjadi diminimalkan dengan suatu mekanisme yang mampu mensejajarkan kepentingan pihak eksternal dan pihak internal. Agency theory memberikan gambaran bahwa masalah manajemen laba dapat dieliminasi dengan pengawasan sendiri melalui good corporate governance. Corporate governance merupakan mekanisme pengendalian untuk mengatur dan mengelolah bisnis dengan maksud untuk meningkatkan kemakmuran dan akuntabilitas perusahaan yang tujuan akhirnya untuk mewujudkan shareholder value. Corporate governanace diperlukan untuk mengendalikan perilaku pengelola perusahaan agar bertindak tidak hanya menguntungkan dirinya sendiri, tetapi juga menguntungkan pemilik perusahaan, atau dengan kata lain untuk menyamakan kepentingan antara pemilik perusahaan dengan mengelola perusahaan.

\section{DAFTAR PUSTAKA}

Assih, P. \& Gudono, M. 2000. Hubungan Tindakan Perataan Laba dengan Reaksi Pasar atas Pengumuman Informasi Laba Perusahaan yang Terdaftar di Bursa Efek Jakarta, Jurnal Riset Akuntansi Indonesia, Vol.3, No1, Januari, Hal. 35-53.

Beneish, M. D. 2001, Earning management a perspektif, Working Paper, Indiana University, Vol.2, April.

Dahlan, Ahmad. 2003. Disclosure dan Corporate Governance: Suatu Tinjauan Teoritis. Tema, Vol.IV.

Darmawati, D. 2003. Corporate Governance dan Manajemen Laba: Suatu Studi Empiris, Jurnal Bisnis dan Akuntansi, Vol. 5, No. 1, April, Hal. 47-68. 
Djakman, C. D. 2003. Manajemen Laba dan Pengaruh Kebijakan Multipapan Bursa Efek Jakarta, Simposium Nasional Akuntansi VI, Oktober, Hal. 141162.

FASB (Financial Accounting Standards Board). 1978. Statement of Financial Accounting Standard No. 1, FASB; USA.

Forum for Corporate Governance in Indonesia. 2001. Peranan Dewan Komisaris dan Komite Audit dalam Pelaksanaan Corporate Governance (Tata Kelola Perusahaan), Jilid II, Edisi Kedua, FCGI, Jakarta.

Gunarsih, Tri. 2003, Struktur Kepemilikan Sebagai Salah Satu Alat Mekanisme Corporate Governance. Kompak 8, hlm. 155-172.

Halim, J., Meiden, C. \& Tobing, R. L. 2005. Pengaruh Manajemen Laba Pada Tingkat Pengungkapan Laporan Keuangan pada Perusahaan Manufaktur yang Termasuk dalam Indeks LQ-45, Simposium Nasional Akuntansi VIII, September, Hal. 117-135.

Healy, P.M., \& J.M. Wahlen.1999. A Review of the Earnings Management Literature and Its Implications for Standard Setting, Accounting Horizon, 13: 365-383.

Herwidayatmo. 2000. Implementasi Good Corporate Governance untuk Perusahaan Publik Indonesia, Manajemen Usahawan Indonesia, No.10, Thn. XXIX, Oktober.

Irfan. 2002. Pelaporan keuangan dan Asimetri Informasi dalam Hubungan Agensi, Lintasan Ekonomi.

Jensen C, \& Meckling.1976. Value Maximation, Stakeholder Theory and the Corporate Objective Function, Working Paper No. 01-09, Harvard Business School.

Khomsiyah. 2003. Hubungan Corporate Governance dan pengungkapan informasi: pengujian secara simultan, Simposium Nasional Akuntansi VI, Oktober, hal 200-219.

Kusindratno, R. \& Sumarta, N. H. 2005. Studi Mengenai Indikasi Manajemen Laba dalam Laporan Keuangan Perusahaan Publik di Bursa Efek Jakarta, Jurnal Ekonomi Unmer, Vol. 9, No. 1, Januari, Hal. 206-221.

Kusuma, H. 2006. Dampak Manajemen Laba terhadap Relevansi Informasi Akuntansi: Bukti Empiris dari Indonesia, Jurnal Akuntansi dan Keuangan.

Mahmudi. 2001. Manajemen Laba (Earnings Management): Sebuah Tinjauan Etika Akuntansi, Jurnal Bisnis dan Akuntansi, Vol. 3, No.2, Agustus, Hal. 395-402. 
Maksum, A. 2005. Tinjauan atas Good Corporate Governance di Indonesia, http://www.usu.ac.id.

Midiastuty, P.P. \& Machfoeds, M. 2003. Analisis Hubungan Mekanisme Corporate Governance dan Indikasi Manajemen Laba, Simposium Nasional Akuntansi VI, Oktober, Hal. 176-186.

Nuryanah, S. 2004. Analisis Ketaatan Emiten terhadap Aturan Board Governance: Studi Kasus Tahun 2002, Simposium Nasional Akuntansi VII, Desember, Hal. 246-255.

OECD, (2004), OECD Principles of Corporate Governance.

Rahmania, M. D. 2007.Analisis Perataan Laba (Income Smoothing): Faktor-faktor yang Mempengaruhi dan Kaitanya dengan Kinerja Saham Perusahaan Publik di Indonesia, Skripsi, Tidak Dipublikasikan, FE Universitas Brawijaya, Malang.

Riyanto, L.S, Bambang. 2005. Corporate Governance : Isu Penelitian, jurnal Kompak, Juli-Desember 2005, hal 163-17.

Satwika, A. \& Damayanti, T. W. 2005. Deteksi Manajemen Laba Melalui Beban Pajak Tangguhan, Jurnal Ekonomi dan Bisnis, Vol. XI, No. 1, Maret, Hal. 119-134.

Scott, W.R. 2003. Financial Accounting Theory, Fifth Edition, Prentice Hall, Toronto.

Setiawati, L. \& Na'im, A. 2000. Manajemen Laba, Jurnal Ekonomi dan Bisnis Indonesia, Vol.15, No. 4, Hal. 424-441.

Susiana. \& Herawaty, A. 2007. Analisis Pengaruh Independensi, Mekanisme Corporate Governance dan Kualitas Audit terhadap Integritas Laporan Keuangan, Simposium Nasional Akuntansi X, Juli, Hal. 1-31.

Ujiyantho, M. A. \& Pramuka B. A. 2007. Mekanisme Corporate Governance, Manajemen Laba dan Kinerja Keuangan, Simposium Nasional Akuntansi X, Juli, Hal. 1-17.

Veronica, Silviana \& Bachtiar, Yanivi, S. 2003. Hubungan antara Manajemen Laba dengan Tingkat Pengungkapan Laporan Kuangan. Simposisum Nasional Akuntansi VI, Surabaya.

Wardhani, Ratna. 2006. Mekanisme Corporate Governance dalam perusahaan yang mengalami permasalahan keuangan, Simposium Nasional Akuntansi 9, Padang. 
Watts, R., \& J. Zimmerman. 1986. Positive Accounting Theory, Prentice-Hall, Englewood Cliffs, N.J.

Wedari, L. K. 2004. Analisis Pengaruh Proporsi Dewan Komisaris dan Keberadaan Komite Audit terhadap Aktivitas Manajemen Laba, Simposium Nasional Akuntansi VII, Desember, Hal. 963-974.

Widyaningdyah, A. U. 2001. Analisis Faktor-faktor yang Berpengaruh Terhadap Earnings Management pada Perusahaan Go Public di Indonesia, Jurnal Akuntansi dan Keuangan, Vol. 3, No. 2, November, Hal. 89-101. 